\title{
Clinical Trials Currently Being Conducted with the Use of Adult Stem Cells Transplantation to Treat Retinal Diseases
}

\section{Rubens c Siqueira}

Department of Ophthalmology, University of São Paulo, Brazil

"Corresponding author: Rubens c Siqueira, Department of Ophthalmology, School of Medicine of Ribeirao Preto, University of São Paulo /USP, Ribeirão Preto, São Paulo, Brazil, E-mail: rubenssiqueira@terra.com.br

Rec date: July 21, 2020, Acc date: July 26, 2020, Pub date: July 28, 2020

Copyright: @ 2020 Siqueira RC. This is an open-access article distributed under the terms of the Creative Commons Attribution License, which permits unrestricted use, distribution, and reproduction in any medium, provided the original author and source are credited.

\section{Editorial}

Current clinical trials are underway to evaluate the potential of stem cell therapy to treat multiple retinal diseases. These trials can be divided into two categories: regenerative and trophic. The regenerative therapies utilize differentiated cells such as RPE or photoreceptors that have been isolated, expanded, and derived from pluripotent embryonic or adult stem cells. The functional cells are intended to replace the damaged native cells to restore retinal function. In the trophic approach, the stem cells remain undifferentiated and are intended to repair the injured tissue or preserve function by altering the cellular microenvironment either by releasing cytokines or cell-to-cell interactions. The ability of regenerative cell therapies to replace diseased tissues has been widely publicized, yet the capacity of trophic therapies to restore visual function also holds promise [1,2]. The mechanisms by which cell therapy may be associated with functional and structural improvements in retinal diseases are unclear, but several stem cell paracrine effects may be important. For example, it has been demonstrated that, when stimulated by pro-inflammatory agents such as tumor necrosis factor, bone marrow mesenchymal stem cells release anti-inflammatory paracrine factors, exerting modulation of local inflammation, which could improve vascular permeability [3-6]. In addition, bone marrow-derived hematopoietic stem cells injected intravitreally have been shown to exert trophic rescue effects in animal models of retinal light-damage, retinal ischemia, and diabetic retinopathy [7-9].

Clinical trials are being conducted by our research group on the safety and efficacy of intravitreal injection of autologous bone marrowderived hematopoietic stem cells (auto-BMHSC) for the treatment of retinitis pigmentosa (RP) (ClinicalTrials.gov:NCT01068561), agerelated macular degeneration (NCT01518127), and retinal vascular diseases with ischemic maculopathy (severe capillary nonperfusion, as per Early Treatment Diabetic Retinopathy Study [ETDRS] criteria) (NCT01518842). We published data regarding the safet and efficacy of intravitreal injection of autologous bone marrow-derived hematopoietic stem cells $(\mathrm{CD} 34+)$ in patients with retinal dystrophy [10], and reported resolution of macular edema in a patient with retinitis pigmentosa [11] and associated with ischemia (due to diabetic retinopathy in one patient and ischemic CRVO in the other patient) (in press). We showed the results of a prospective, single blind, phase II, nonrandomized clinical trial, including 20 retinitis pimentosa patients and we observed a small improvement of macular thresholds on microperimetry, concomitant to a slight hindering of the 30-2 visual field sensitivity deterioration, one year after injection [12].

We chose this route because intravitreal route has less risk and more routinely used in clinical practice compared to subretinal route. Some questions related to the use of intravitreal route are still controversial, for example, the survival time of these cells into the vitreous, the ability to penetrate these cells in the retina, the capacity of transdifferentiation in retinal cells and also if the neurotrophic factors which are produced by these cells act on the retina.

Park et al. experimentally evaluated the behavior of stem cells derived from bone marrow when injected intravitreally with respect to survival and clinical effect. They identified that the CD34 cells were injected intravitreally, were in the retinal vasculature in the fourth month after the injection and presented clinical effect observed in the electroretinogram until the eighth month [13]. This same author also initiated a pilot study that was presented at ARVO 2014 with the use of Intravitreal Autologous Bone Marrow CD34+ Stem Cell Therapy for Macular Degenerative Disease. In this report, three eyes (three subjects) were enrolled (one with dry atrophic age-related macular degeneration (AMD); two with Stargardt's disease). The bone marrow aspiration and intravitreal injection of cells were well-tolerated and without any adverse effects during the follow-up period. A total of 3 to 7 million CD34+ cells were isolated and injected intravitreally per eye. BCVA improved 1.5 to 4 lines in the study eye during the follow-up period. No funduscopic or angiographic changes were noted during the follow-up except for some mild progression of geographic atrophy extrafoveally in both eyes of the AMD subject. Multifocal ERG showed a trend toward stabilization in the study eye compared to the contralateral eye. Full-field ERG showed stable or enhanced amplitude in the study eye. AO-OCT imaging showed new punctuate hyperreflectivity within the retinal layers suggestive of intraretinal incorporation of the stem cells in the eye with Stargardt's disease [14].

Stem cell transplantation for retinal disease is currently transitioning from over a decade of preclinical research to phase I/II clinical trials. The results of these trials are keenly anticipated, not just regarding efficacy but also to elucidate the levels of immunosuppression required, the difference between RPE replacement and paracrine models, and to determine which delivery method is preferable. A new avenue for the treatment is being opened, and soon we will have answers regarding the cell type and technique will be more effective and safe for each group of retinal diseases.

\section{References}

1. Tibbetts MD, Samuel MA, Chang TS, Ho AC (2012) Stem cell therapy for retinal disease. Curr Opin Ophthalmol 23:226-234.

2. Siqueira RC (2011) Stem cell therapy for retinal diseases: update. Stem Cell Res Ther 2: 50.

3. Siqueira RC, Voltarelli JC, Messias AM, Jorge R (2010) Possible mechanisms of retinal function recovery with the use of cell therapy with bone marrow-derived stem cells. Arq Bras Oftalmol 73: 474-479.

4. Crisostomo PR, Markel TA, Wang Y, Meldrum DR (2008) Surgically relevant aspects of stem cell paracrine effects. Surgery 143:577-581. 
Citation: Siqueira RC (2020) Clinical Trials Currently Being Conducted with the Use of Adult Stem Cells Transplantation to Treat Retinal

Page 2 of 2

5. Cheng AS, Yau TM (2008) Paracrine effects of cell transplantation: strategies to augment the efficacy of cell therapies. Semin Thorac Cardiovasc Surg 20:94-101.

6. Markel TA, Crisostomo PR, Wang M, Herring CM, Meldrum DR (2007) Activation of individual tumor necrosis factor receptors differentially affects stem cell growth factor and cytokine production. American journal of physiology. Am J Physiol Gastrointest Liver Physiol 293: G657-G662.

7. Zhang Y, Wang W (2010) Effects of bone marrow mesenchymal stem cell transplantation on light-damaged retina. Invest Ophthalmol Vis Sci 51: 3742-3748.

8. Li N, Li XR, Yuan JQ (2009) Effects of bone-marrow mesenchymal stem cells transplanted into vitreous cavity of rat injured by ischemia/ reperfusion. Graefes Arch Clin Exp Ophthalmol 247: 503-514.

9. Otani A, Dorrell MI, Kinder K, Moreno SK, Nusinowitz S, et al. (2004) Rescue of retinal degeneration by intravitreally injected adult bone marrow-derived lineage-negative hematopoietic stem cells. J Clin Invest 114: 765-774.

10. Siqueira RC, Messias A, Voltarelli JC, Scott IU, Jorge R (2011) Intravitreal injection of autologous bone marrow-derived mononuclear cells for hereditary retinal dystrophy: a phase I trial. Retina 31: 1207-1214.

11
Siqueira RC, Messias A, Voltarelli JC, Messias K, Arcieri RS, et al. (2013) Resolution of macular oedema associated with retinitis pigmentosa after intravitreal use of autologous BM-derived hematopoietic stem cell transplantation. Bone Marrow Transplant 48: 612-613.

12. Arcieri RS, Messias K, Castro VM, Siqueira RC, Jorge R, et al. (2013) Intravitreal Autologous Bone-Marrow Stem Cells in Retinitis Pigmentosa Patients: One-Year Results. The Association for Research in Vision and Ophthalmology, Inc. (ARVO) 2013 Annual Meeting. Seattle, Wash-USA.

13. Park SS, Caballero S, Bauer G, Shibata B, Roth A, et al. (2012) Long-term effects of intravitreal injection of GMP-grade bone-marrow-derived CD34+ cells in NOD-SCID mice with acute ischemia-reperfusion injury. Invest Ophthalmol Vis Sci 53: 986-994.

14. Park SS, Bauer G, Panorgias A, Zawadzki, Robert J, et al. (2014) Intravitreal Autologous Bone Marrow CD34+ Stem Cell Therapy for Macular. The Association for Research in Vision and Ophthalmology, Inc. (ARVO) 2014 Annual Meeting, Orlando-Florida-USA. 